\title{
Lung Deposited Surface Area in Leicester Urban Background Site/UK: Sources and Contribution of New Particle Formation
}

Sarkawt M.L Hama [1][2], Nan Ma [3], Rebecca L. Cordell [1], Gerard P.A. Kos [4], Alfred

Wiedensohler [3] and Paul S. Monks [1]

[1] Department of Chemistry, University of Leicester, Leicester LE1 7RH, UK

[2] Department of Chemistry, School of Science, University of Sulaimani, Sulaimani, Iraq

[3] Leibniz Institute for Tropospheric Research, Permoserstr. 15, 04318 Leipzig, Germany

[4] Energy research Centre of the Netherlands (ECN), Environment \& Energy Engineering, the Netherlands

Correspondence to: Paul S. Monks (psm7@1e.ac.uk), Nan Ma (ma@tropos.de)

\section{Highlights}

- Clear seasonal variation of Lung Deposited Surface Area (LDSA) concentrations is observed with higher values in winter.

- Calculated LDSA seems to be a good surrogate to equivalent black carbon mass concentration.

- Traffic emissions appear to be the main source of LDSA in Leicester.

- LDSA concentrations are nearly doubled during new particle formation episodes.

\section{Keywords:}

- Aerosol

- Seasonal variation

- Traffic emissions

- Lung deposited surface area 
2 Lung Deposited Surface Area (LDSA) has been identified as a potential metric for the

3 correlation of a physical aerosol particle properties with health outcomes. Currently, there is

4 little urban LDSA data. As a case study, we investigated measurements of LDSA (alveolar) 5 concentrations in a mid-size European city. LDSA and associated measurements were carried 6 out over 1.5 years at an urban background site in Leicester, UK. Average LDSA concentrations 7 in the cold (November-April) and warm (May-October) seasons of UK were 37 and $23 \mu \mathrm{m}^{2}$ $8 \mathrm{~cm}^{-3}$, respectively. LDSA correlates well $\left(\mathrm{R}^{2}=0.65-0.7, \mathrm{r}=0.77-0.8\right)$ with traffic related 9 pollutants, such as equivalent black carbon $(\mathrm{eBC})$ and $\mathrm{NO}$. We also report for the first time in 10 the UK the correlation between an empirically derived LDSA and eBC. Furthermore, the effect of wind speed and direction on the LDSA was explored. Higher LDSA concentrations are observed at low wind speeds $\left(1-2 \mathrm{~m} \mathrm{~s}^{-1}\right)$, owing to local traffic emissions. In addition, the diurnal variation of LDSA showed a second peak in the afternoon under warm and relatively clean atmospheric conditions, which can be attributed to photochemical new particle formation (NPF) and growth into the Aitken mode range. These NPF events increased the average background LDSA concentrations from 15.5 to $35.5 \mu \mathrm{m}^{2} \mathrm{~cm}^{-3}$, although they might not be health-relevant. Overall, the results support the notion that local traffic emissions are a major contributor to observed LDSA concentrations with a clear seasonal pattern with higher values during winter. 
2 The surface area concentration is an important property of atmospheric aerosol particles which

3 links aerosol loading to its health effects. Over recent years a number of epidemiological studies

4 have shown that atmospheric particle surface area concentration may have a stronger correlation with negative health effects than particle mass or number concentration (Brown et al., 2001; Brown et al., 2000; LeBlanc et al., 2010; Nel et al., 2006; Nurkiewicz et al., 2009; Nygaard et al., 2004; Oberdörster et al., 2005; Sager and Castranova, 2009; Singh et al., 2007; Stoeger et al., 2006; Tran et al., 2000). Toxicological studies have found that ultrafine particles may have an increased toxicity compared to larger particles with the same composition (Johnston et al., 2000; Karlsson et al., 2009), and that the surface area concentration might be the most relevant physical measurement of ultrafine particle exposure (Maynard and Maynard, 2002; Moshammer and Neuberger, 2003; Oberdörster, 2000). All these studies reveal that the surface area concentration of atmospheric particles in various environments is a suitable property to represent the negative human health effects of aerosol exposure.

Instruments based on unipolar diffusion charging of particles or lung-deposited surface area (LDSA) concentrations (NSAM model 3550 and AeroTrak TM 9000, TSI Inc), (Bau et al., 2012) can measure a value related to particle surface area concentration and are more sensitive to ultrafine particles than gravimetric methods (e.g., Gravimetric Filter Method and Mass PM Analyser, (Mohr et al., 2005)). Such instruments may offer the ability to explore source-related ultrafine particle exposure as they deliver high temporal and potentially spatially disaggregated measurements, which addresses requirements around the nature of ultrafine particles to coagulate quickly and create significant concentration gradients (Imhof et al., 2005; Peters et al., 2009). In these instruments a corona discharge produces unipolar ions, which can diffuse towards the particles and an electrometer is used to measure the total charge that transfers from the ions to the particles; the amount of charge is related to the active surface area concentration (Asbach et al., 2009; Baltensperger et al., 2001).

LDSA concentrations have been reported at urban background sites in Upper Austria (Moshammer and Neuberger, 2003), Minneapolis (Wilson et al., 2007), Los Angeles (Ntziachristos et al., 2007), Lisbon (Albuquerque et al., 2012; Gomes et al., 2012), Italy 30 (Buonanno et al., 2012; Buonanno et al., 2010; Geiss et al., 2016; Spinazzè et al., 2015), 31 Switzerland (Eeftens et al., 2015; Fierz et al., 2011), Barcelona (Reche et al., 2015), Helsinki 32 (Kuuluvainen et al., 2016). However, the concentrations of LDSA in UK cities have not been 
1 reported in any previous studies and it is important to know the levels of the LDSA in UK as a

2 reference for future studies.

3 The aim of the present study is to explore extra-annual cycles of LDSA in a mid-size urban

4 environment. In addition, the association of the calculated LDSA with equivalent black carbon

5 mass concentration (eBC) was investigated to assess the relationship of LDSA to human health.

6 Further, to our knowledge the study represents the first that reveals variability of LDSA and the

7 impact of new particle formation (NPF) on LDSA in the UK.

8 The study was carried out between November 2013 and May 2015 over which time aerosol

9 lung deposited surface area (LDSA) concentrations in the alveolar region were measured

10 concurrently with equivalent black carbon mass concentration, nitrogen oxides concentration

11 (NOx), and particle number size distributions (PNSD) at Automatic Urban Rural Network

12 (AURN) site in the Leicester city (UK), where air quality is mainly influenced by traffic

13 emissions owing to the high vehicle density across the city. This study builds on measurements

14 developed as part of an ultrafine particle air quality monitoring network, established in in 15 Amsterdam (Netherlands), Antwerp (Belgium), Leicester (UK) and London (UK) in the JOint 16 Air QUality INitiative (JOAQUIN, www.joaquin.eu), an INTERREG IVB funded European 17 project, which aimed at supporting health-oriented air quality policies in Europe (Cordell et al., 18 2016; Hofman et al., 2016).

19 


\section{Experiment}

The study was carried out between November 2013 and May 2015 over which time aerosol LDSA concentrations in the alveolar region were measured concurrently with eBC, $\mathrm{NO}_{\mathrm{X}}$, and PNSD at AURN site in the Leicester city (UK), where air quality is mainly influenced by traffic emissions owing to the high vehicle density across the city.

\subsection{Monitoring site}

In the JOAQUIN project, a range of air quality parameters (including PNSD, eBC, NOx, LDSA and $\mathrm{PM}_{10}$ ) were measured in six cities in North West Europe; Amsterdam and Wijk an Zee (The Netherlands), Antwerp (Belgium), Leicester and London (United Kingdom), Lille (France) (Cordell et al., 2016; Hofman et al., 2016). Data collection started in April 2013 (Amsterdam, Antwerp), November 2013 (Leicester) and April 2014 (London). To check the stability and comparability of the air quality monitors, a mobile monitoring unit performed measurements adjacent to the fixed air quality monitoring stations. The PNSD and eBC monitors and $\mathrm{PM}_{10}$ sampler were identical to that for the permanent JOAQUIN stations. The detail of the project and information about sites and instrumentation can be found in Joaquin (2015) as well as Hofman et al. (2016) and Cordell et al. (2016).

Measurements were carried out at two sites in Leicester as part of the JOAQUIN project. The main and permanent site represents an urban background and is part of the UK government operated AURN. The site was located at the University of Leicester campus (http://uk air.defra.gov.uk/networks/site-info?uka id=UKA00573), as shown in Figure 1. For contrast, a temporary site at Brookfield (See Figure 1) was developed with a mobile monitoring station in a large and frequently-used car park. The Brookfield site also represents urban background (Figure 1), and was located at a distance of approximately $1.2 \mathrm{~km}$ east of the AURN site.

At the AURN site the nearest road is University Road (20 m North-West) with very little traffic and the nearest main road is Welford Road (140 m South-South West). According to traffic counts by the Department for Transport (UK government), the traffic intensity of Welford Road was about 22,600 vehicles/day in 2014 (http://www.dft.gov.uk/traffic-counts, count point 36549). At the temporary site, the nearest roads are Ashfield Road (90 $\mathrm{m}$ in the North) and Holmfield Road (90 m South) and the nearest main road is London Road, at $190 \mathrm{~m}$ west. According to traffic counts by the Department for Transport, the traffic intensity on London 
1 Road was approximately 20,550 vehicles/day in 2014 (http://www.dft.gov.uk/traffic-counts, count point 56147).

\subsection{Instrumentation}

Table 1 gives a summary of the instruments used in this study at both sites. In the AURN station in Leicester, lung deposited surface area (LDSA) was measured by a Nanoparticle Surface Area Monitors (NSAM, TSI 3550) originally developed by Fissan et al. (2007). The NSAM operational principle is based on diffusion charging of particles followed by detection of the charged aerosol using an electrometer. The instrument can be switched between two sampling modes: the tracheobronchial and alveolar fractions of the total particle. The NSAM monitor was designed to report the surface area of particles only deposited in the alveolar and tracheobronchial regions when the ion trap voltage is set to $200 \mathrm{~V}$ and $100 \mathrm{~V}$, respectively (Asbach et al., 2009). In this study the NSAM was set to measure the alveolar lung-deposited particle surface area (reported as $\mu \mathrm{m}^{2} \mathrm{~cm}^{-3}$ ). It was operating at 1 minute time resolution during the whole study period (November 2013-May 2015) with a data coverage of $99 \%$. The inlet flow rate is $2.5 \mathrm{~L} / \mathrm{min}$, of which $1.5 \mathrm{~L} / \mathrm{min}$ is used as aerosol flow. The NSAM detects particles size range approximately from 10 to $1000 \mathrm{~nm}$, however, it measures only up to $400 \mathrm{~nm}$ with high precision (Asbach et al., 2009). According to Asbach et al. (2009), particle hygroscopicity may cause significant changes in the lung deposition curves, which is a factor that cannot be measured by this instrument.

The particle number size distributions were measured by a Mobility particle size spectrometer (type Grimm SMPS+C 5420 with L-DMA). The size spectrometer consists of a Neutralizer $\left({ }^{85} \mathrm{Kr}\right.$ source, $185 \mathrm{MBq}$, obtained from Eckert \& Ziegler) and a Differential Mobility Analyzer (Vienna type L-DMA, $50 \mathrm{~cm}$ long), connected to a butanol-based Grimm-type condensation particle counter $(\mathrm{CPC})$. The flow rate of the $\mathrm{CPC}$ is $0.3 \mathrm{~L} / \mathrm{min}$. To measure a $10-1100 \mathrm{~nm}$ range, the sheath air flow rate is $3 \mathrm{~L} / \mathrm{min}$. A complete scan of the particle number size distribution with 45 size bins was done in $10 \mathrm{~min}$. The software corrects for internal diffusion losses and the bipolar charge distribution (Wiedensohler, 1988). Aerosol was kept at low relative humidity (RH) with a Nafion dryer in the inlet system. However, such a drying system can leads to extra losses of the small particles $(<70 \mathrm{~nm})$. Although in JOAQUIN project these losses were calculated and corrected for, the losses might have been higher, as can be derived from field tests (Joaquin, 2015; Wiedensohler et al., 2012). 
1 The total particle number concentration ( $\mathrm{N}_{\text {TOTAL }}$ ) was measured by a Water-Based

2 Condensation Particle Counter (W-CPC, TSI Environmental Particle Counter (EPC) model

33783 http://www.tsi.com/environmental-particle-counter-3783) from November 2013 to May

42015.

5 The TSI instruments (W-CPC and NSAM) are connected to environmental sampling system

6 (TSI 3031200). The components of the TSI 3031200 are a $\mathrm{PM}_{10}$ inlet, sharp cut $\mathrm{PM}_{1}$ cyclone,

7 flow splitter and Nafion dryer (reduces humidity to less than $50 \% \mathrm{RH}$ ).

8 The mass concentration of equivalent black carbon (eBC) was measured by a Multi-angle 9 Absorption Photometer (MAAP Thermo Scientific model 5012) for the whole period (Petzold 10 et al., 2013). The MAAP determines particle light absorption owing to the light transmission 11 and backscattering at two angles of particles collected on the filter tape (glass fibre type GF10). 12 The eBC mass concentration is calculated using a constant mass absorption cross section of 6.6 $\mathrm{g} / \mathrm{m}^{2}$. Further information on the principle of the MAAP is given by Petzold et al. (2002).

14 Nitrogen oxides were also measured by a Thermo $42 \mathrm{i} \mathrm{NO}-\mathrm{NO}_{2}-\mathrm{NO}_{\mathrm{x}}$ monitor. This monitor uses chemiluminescence technology to measure the concentration of nitrogen oxides in the air. It has a single chamber, single photomultiplier tube design that cycles between the $\mathrm{NO}$ and $\mathrm{NO}_{\mathrm{x}}$ mode. Meteorological data (wind speed and direction) were provided for the whole period by the Air

19 Quality Group from the Leicester City Council. The station is located $4.9 \mathrm{~km}$ away from the 20 AURN urban background monitoring site. Moreover, a mobile laboratory van also measured metrological parameters (temperature, relative humidity, and wind speed and direction) during the three months of mobile monitoring. 


\section{Results and Discussion}

\subsection{The annual behaviour of LDSA, eBC and NOx concentrations}

The data were split into three time periods consisting of a so-called the cold period (November to April), the warm period (May to October) as well as the whole period. Statistics for LDSA, $\mathrm{eBC}$, and NOx concentrations are shown in Table 2. During this study, the annual average LDSA concentrations in Leicester was $29.5 \mu \mathrm{m}^{2} \mathrm{~cm}^{-3}$, and the maximum, median, minimum and standard deviation annual values were, 282.8, 22.3, $0.1,24.8 \mu \mathrm{m}^{2} \mathrm{~cm}^{-3}$ respectively. The statistics are based on $30 \mathrm{~min}$ data. The mean LDSA concentration measured at Leicester AURN site was observed to be similar to that found at traffic sites in Zurich, Switzerland (28$40 \mu \mathrm{m}^{2} \mathrm{~cm}^{-3}$ )(Fierz et al., 2011). Previous LDSA measurements are summarised in Table 3.

Monthly variation of LDSA concentrations, with other air quality parameters, such as eBC and NOX is shown in Figure 2. A clear seasonal variation was observed for the LDSA, eBC and NOx concentrations. The high concentrations of LDSA observed in the cold period in Leicester (November-April) with a $30 \mathrm{~min}$ average range between $37-38.5 \mu \mathrm{m}^{2} \mathrm{~cm}^{-3}$. The seasonal enhancement might be related to the increase of wood burning for domestic heating, as well as reduced dispersion of local sources and low mixing height in the winter time (Cordell et al., 2016). The lowest LDSA concentrations were observed in summer (July and August) when the average values ranged between $19-21 \mu^{2} \mathrm{~cm}^{-3}$. The summer minima are likely related to the metrological conditions that have greater impact, particularly the effective dilution of particles owing to stronger turbulent mixing. The dilution effects are caused by metrological conditions, for instance wind direction and speed, which control horizontal dilution, and the mixing layer height, which controls the vertical extent. The impact of meteorology on LDSA are discussed in detail in section 3.4. The lower LDSA levels in summer might also be due to loss of semivolatile particle material during the warm period. Similar patterns where observed for eBC and NOx concentration in comparison to LDSA (see Figure 2). The similarity is likely due to LDSA and other parameters (eBC and NOx) being influenced by the same factors such as traffic emissions, vertical dilution conditions and metrological conditions (mixing height, and temperature). The uncertainty bars shown in Figure 2 represent the standard deviations based on the 30 minute values of LDSA, eBC, and $\mathrm{NO}_{\mathrm{X}}$ concentrations. Higher standard deviations are observed during the cold period and this could be related to the contrast of different weather systems that in cold season is stronger than in warm season. It may be also linked to the 
inversion conditions, suspension of aerosol particles for longer, lower wind speed and build-up of LDSA as well as other parameters under favorable inversion conditions.

\subsection{Diurnal and Weekly variations of LDSA, eBC, and NOx}

The average weekly variations of the LDSA, eBC and NOx concentrations are shown in Figure 3. The diurnal variation of the three parameters is mainly determined by the emission pattern of the dominant sources and the evolution of the mixing layer. The average diurnal patterns of LDSA, eBC, and $\mathrm{NO}_{\mathrm{X}}$ based on half-hour means are quite similar in shape. The main sources of $\mathrm{eBC}$ in urban atmosphere are diesel vehicles and domestic heating while $\mathrm{NO}_{\mathrm{X}}$ is mainly from traffic emissions (Carslaw, 2011; Viana et al., 2012). During the cold period the impact of traffic was obvious on workdays (Monday-Friday) when the highest LDSA concentration was measured during morning and evening rush hours, between 6:00 - 9:00 LT and 18:00-21:00 LT respectively. This is seemingly associated to the result of the high motor vehicle emissions combined with a lower mixing layer height and lower temperature (Reche et al., 2015). Peaks of LDSA concentrations were also observed on workday morning rush hour during the warm period, but with lower absolute values than in the cold period. A similar profile was observed for eBC and NOx concentrations when compared with LDSA. The similar patterns suggest that LDSA is influenced by mainly the traffic emissions in Leicester urban area. The LDSA evening rush hour peaks in summer months were usually lower than the morning rush hour peaks likely related to the stronger turbulent mixing and higher mixed layer depths, also higher wind speed. It can be concluded that the late afternoon peak is more influenced by local meteorology conditions than by vehicular exhaust emissions. Interestingly, the LDSA pattern shows an additional peak in the afternoon during the warm months. This phenomena might be related to the NPF (see Section 3.5). The diurnal variations of the $\mathrm{eBC}$, and $\mathrm{NO}_{\mathrm{X}}$ concentrations observed in this work are in line with those observed in other studies for traffic pollutant dominated locations (Gomišček et al., 2004; Harrison et al., 1997; Jones and Harrison, 2005; Laxen et al., 2010).

There is other evidence that is confirmative to the relationship between LDSA concentration and traffic emissions. During the weekends, the diurnal variations for LDSA, eBC and $\mathrm{NO}_{\mathrm{X}}$ are similar, but differ from those on weekdays. Without traffic rush hours, lower concentrations were observed in the early morning. Moreover, the LDSA evening peak on weekends in the cold period shows higher than that observed during the warm period. This observation might 
1 be related to the increasing traffic activity owing to that people are going out for restaurants or

2 shopping at late afternoon, and also may impact of higher emissions from cooking and domestic

3 heating when people staying at home during weekends (Allan et al., 2010). Additional weekend contributions to LDSA stem from events such as barbeques and late night activities on Saturdays, which result in a peak occurring later in the day and lasting for longer.

\subsection{Correlation between LDSA and other pollutants (eBC, NOx and NTOTAL)}

To assess the relation of LDSA with more commonly monitored pollutants, half-hourly LDSA were plotted against half-hourly eBC, $\mathrm{NO}_{\mathrm{X}}$ and $\mathrm{N}_{\mathrm{TOTAL}}$. The scatter plots between LDSA and the other parameters from November 2013 to April 2015 at the AURN site are presented in Figure $4 \mathrm{a}-\mathrm{c}$. The $\mathrm{R}^{2}$ for LDSA with $\mathrm{eBC}, \mathrm{NO}_{\mathrm{X}}$ and $\mathrm{N}_{\mathrm{TOTAL}}$, were $0.52,0.36$, and 0.60 (Figure 4a-c), and Pearson's correlation coefficients were $0.81,0.77$, and $0.80(\mathrm{p}<0.05)$, respectively. These results are similar to results from Barcelona (Reche et al., 2015). In addition, seasonal correlation between LDSA and the other pollutants were also observed (Figure 5a-c). The correlation considerably increased when only using the cold period (Autumn and Winter) data. The highest correlation $\left(\mathrm{R}^{2}=0.59-0.71\right)$ in the cold season was found between the LDSA and the $\mathrm{eBC}$ and $\mathrm{NO}_{\mathrm{x}}$ as compared with the summer months. The higher correlation indicates that LDSA in cold season is more dominated by anthropogenic emission such as traffic and heating. The weaker correlation was observed between LDSA and the eBC in summer and with NOx in spring and summer $\left(\mathrm{R}^{2}=0.34-0.35\right)$, suggesting that the LDSA in spring and summer might be affected by photochemical new particle formation. The LDSA and $\mathrm{N}_{\text {TOTAL }}$ concentrations in all seasons were relatively well correlated $\left(\mathrm{R}^{2}=0.51-0.7\right)$; Overall, it can be concluded that these correlations between LDSA with other parameters support the annual behavior and diurnal variations of LDSA (discussed in section 3.1 and 3.2) in that the LDSA concentrations in Leicester urban area are mainly dominated by road transport emissions.

The correlation between LDSA and different size range of particle number concentrations measured by SMPS (not shown) agreed with the results found in the previous study by Reche et al. (2015). The results showed that the highest correlation between LDSA and particle number size in the range 50-200 $\mathrm{nm}$. However, low correlation was observed between LDSA and particle number concentrations in the size range 10-30 nm, as these particles are outside the NSAM size range $(20-400 \mathrm{~nm})$. In addition, a proxy LDSA was calculated from SMPS particle size distributions for the entire period by the method described in (Reche et al., 2015). 
1 The highest correlation $\left(\mathrm{R}^{2}=0.89\right)$ between the measured LDSA (from NSAM) and calculated

2 LDSA from PNSD encompassed the range 20-400 $\mathrm{nm}$ (see Figure 6a-d). In addition, the 3 correlation between calculated LDSA (30-200 nm) and eBC are shown in Figure 7. The limit 4 size range of calculated LDSA $(30-200 \mathrm{~nm})$ is selected to cover the main size range for eBC (Petzold et al., 2013; Pósfai et al., 2004; Schwarz et al., 2006). Figure 7a shows a good correlation $\left(\mathrm{R}^{2}=0.6-0.75, \mathrm{r}=0.82\right)$ between the calculated LDSA and $\mathrm{eBC}$, as well as similar diurnal profile for the calculated LDSA and eBC (Figure 7b). The level of agreement between $\mathrm{eBC}$ and the calculated LDSA indicates that $\mathrm{eBC}$ might be a good indicator, measure or estimate of health impacts in relation to LSDA.

\subsection{Variation with wind speed and direction}

Meteorological parameters play significant roles in determining the concentration levels of air pollutants in urban areas. Previous studies have shown that among the meteorological parameters, wind speed is a significant factor governing the eBC and NOx concentrations (Carslaw et al., 2006; Xu et al., 2011). In order to investigate the impact of wind speed and direction on LDSA, as well as eBC and NOx concentrations, wind map plots were generated for showing the impact of wind conditions on these parameters (see Figure 8). Figure 8a-c shows the wind dependence of the LDSA, $\mathrm{eBC}$, and $\mathrm{NO}_{\mathrm{x}}$ concentrations generated using the half-hourly data from Nov 2013 to May 2015. A polar coordinate system was used dependent on wind speed and direction (Ma et al., 2011; Xu et al., 2011). For LDSA, the maximum concentration (Figure 8a) occurs with calm winds (wind speed $<2 \mathrm{~m} \mathrm{~s}^{-1}$, the red and yellow areas in the center of the plots), independent of wind direction. This again reflects a combination of sources i.e. local emissions such as, traffic and domestic heating and particulate size. What is clear from the polar plots is that the contribution of emissions from the surrounding regions is weak. It can be observed the highest average LDSA (dash-dot line) is from the south and north westerly wind direction, affected by the transport of aerosols from both directions. The major roads, the East Midlands airport and Radcliffe upon Soar power station (both of which are around 16.03 miles far from AURN station) are situated in the South and North Westerly regions. For eBC, a similar feature was observed, the maximum eBC (Figure 8b) occurring when wind speed below $2 \mathrm{~m} \mathrm{~s}^{-1}$. In the NW and SW directions, eBC concentrations were higher for wind speed higher than $4 \mathrm{~m} \mathrm{~s}^{-1}$. The reason being that $\mathrm{eBC}$ is being transported from regions lying in those directions. For $\mathrm{NO}_{\mathrm{x}}$, similar patterns to LDSA and $\mathrm{eBC}$ are observed 
1 with high NOx (Figure 8c) levels found under low wind speeds $\left(<2 \mathrm{~m} \mathrm{~s}^{-1}\right)$. It can be supposed that NOx is mainly dominated by local sources and emissions. Under such an assumption, levels of $\mathrm{NO}_{\mathrm{X}}$, should display a simple decreasing trend with increasing wind speed to a background level. Such a relationship between $\mathrm{NO}_{\mathrm{X}}$ and wind speed was found as well as modelled in previous studies (Aldrin and Haff, 2005; Carslaw et al., 2006). The wind rose data support the supposition that LDSA is dominated by local emissions, including traffic and domestic heating emissions. Figure $8 \mathrm{~d}$ shows a wind rose for the whole sampling period.

\subsection{Contribution of new particle formation to LDSA}

A recent study in Barcelona identified that NPF events affect LDSA concentration in an urban area (Reche et al., 2015). Within northern Europe, in Birmingham and Helsinki nucleation events in urban atmosphere have been previously observed during noon hours with a maximum during the spring season (Alam et al., 2003; Hussein et al., 2008).

Over the SMPS sub-set period (3 months) of our work 14 NPF event days where observed. A typical one was the nucleation event with particle growth observed on May 3rd, 2014 as shown in Figure 9. During the event the peak wind speed observed was $2.3 \mathrm{~ms}^{-1}$, a SE wind dominated in the morning and a SW wind dominated in the afternoon, and the relative humidity remained low at $30-40 \%$. To explore the significance of nucleation events on the LDSA concentration, particle number size distribution $(10-1000 \mathrm{~nm})$ were studied. The nucleation events characterised by a clear growth in particle size over a long period of time result in the classical "banana" shape (Heintzenberg et al., 2007; Kulmala and Kerminen, 2008). A clear example of "banana-like" nucleation event is shown in Figure 9. The nucleation mode particles are observed in the morning, and starts to grow in size at around 10:00, indicated as the increase of 10-20 $\mathrm{nm}$ particle number concentrations. Moreover, during the event particle number concentrations increased from 4837 particles $\mathrm{cm}^{-3}$ at 10:00 and reached the highest number 12060 particles $\mathrm{cm}^{-3}$ around 13:30. Total particle volume concentrations were calculated by integrating the number size distributions of size-resolved particles assuming spherical particles as shown in the lowest panel of Figure 9. During the NPF event (from 10:00-18:00) the volume concentration has not been significantly increased. The reason is that new particles are small (10-20 nm), and therefore their contribution to the particle volume is insignificant (Wehner and Wiedensohler, 2003). However, between 18:00-20:00, the volume concentration shows a peak, this probably owing to the influence of traffic emissions which is coincides with evening rush 
1 hours. The particle number size distributions showed a clear 'banana' shape, lasting from 10:00

2 up to 18:00, indicated as high levels of 20-50 nm particle number concentrations owing to the

3 growth of newly formed particles to larger particle sizes. During the NPF event LDSA 4 concentrations increased nearly doubly (from $15.5 \mu \mathrm{m}^{2} \mathrm{~cm}^{-3}$ to $35.5 \mu \mathrm{m}^{2} \mathrm{~cm}^{-3}$ ) which is comparable to results from a previous study in urban Barcelona (Reche et al., 2015) where an LDSA increase was observed during such an event. In addition, the LDSA continues to increase after 18:00 until 22:00. This is probably being linked to the anthropogenic emissions (such as traffic and domestic heating emissions) and also may effect of NPF on LDSA concentration. Significant increase of eBC concentrations during the event are not observed, but a slight increase is observed after 15:00 that might be related to the traffic emissions; the average black carbon concentration was $0.58 \mu \mathrm{g} \mathrm{m}^{-3}$, lower than before and after the event at $1.59 \mu \mathrm{g} \mathrm{m}^{-3}$ and $1.53 \mu \mathrm{g} \mathrm{m}^{-3}$, respectively. Previous studies in the urban atmosphere of Singapore (Betha et al., 2013) and Barcelona (Reche et al., 2011) showed similar trends in the diurnal variation of black carbon during the NPF events.

To explore further the overall impact and extent of NPF on LDSA, the diurnal variation of PNSD and LDSA for the NPF and non-NPF event days where averaged as shown in Figure 10a, and $\mathrm{b}$. Figure 10a clearly shows the LDSA peak follows NPF peak while NOx does not. Figure 10b shows the diurnal variation of non-NPF event days, it can be seen there is no peak for the nucleation mode particles and also LDSA has similar profile as nucleation mode particles. There seems to be a generaliseable phenomenon that the NPF events can contribute to an increase in LDSA, though there is a need to extend this to full seasonal coverage.

\section{Conclusions}

In this study, LDSA concentrations and PNSD have been measured in the Leicester urban atmosphere along with observations of $\mathrm{eBC}$, and $\mathrm{NOx}$ concentrations. The annual average LDSA concentration during this study was $29.5 \mu \mathrm{m}^{2} \mathrm{~cm}^{-3}$, which was lower than previously measured at most other urban backgrounds with the exception of Zurich where the urban background was very low. Strong seasonal values of LDSA, as well as eBC, and NOx, were measured owing to the influence of metrological parameters and dilution effects. Furthermore, 
1 the diurnal variation of LDSA concentrations observed can be rationalised in terms of the

2 influence of traffic emissions and any dilution effects.

3 An additional peak was also observed in the afternoon, during the warm season, which could

4 be attributed to NPF events, owing to its occurrence at a time when high traffic emissions are 5 not normally observed. The existence of NPF events are confirmed by the gradual increase in 6 LDSA concentration to approximately double their initial values. Increases in LDSA occurred 7 whilst eBC concentrations were low, suggesting that the LDSA did not originate from a fossil

8 fuel combustion source, indicating NPF may be another source of LDSA.

9 Overall it can be concluded that vehicle emissions and biomass burning, particular domestic 10 heating in cold season, in an urban area such as Leicester are the main sources of increased 11 LDSA, eBC and also particle number concentrations.

\section{Acknowledgements}

13 The authors would like to thank the Human Capacity Development Program from the Kurdistan 14 Government for a scholarship (S. M. L. HAMA). We would like also to thank Dr Jolanta 15 Obszynska (Leicester City Council) for providing meteorological data. This research was 16 funded by the Joint Air Quality Initiative (JOAQUIN) project, part of the EU Interreg IV-B 17 NWE Program. 
Alam, A., Shi, J.P., Harrison, R.M., 2003. Observations of new particle formation in urban air. Journal of Geophysical Research: Atmospheres 108, n/a-n/a.

Albuquerque, P.C., Gomes, J.F., Bordado, J.C., 2012. Assessment of exposure to airborne ultrafine particles in the urban environment of Lisbon, Portugal. Journal of the Air \& Waste Management Association 62, 373-380.

Aldrin, M., Haff, I., 2005. Generalised additive modelling of air pollution, traffic volume and meteorology. Atmospheric Environment 39, 2145-2155.

Allan, J.D., Williams, P.I., Morgan, W.T., Martin, C.L., Flynn, M.J., Lee, J., Nemitz, E., Phillips, G.J., Gallagher, M.W.a.C., H. , 2010. Contributions from transport, solid fuel burning and cooking to primary organic aerosols in two UK cities. Atmospheric Chemistry and Physics 10, 647-668.

Asbach, C., Fissan, H., Stahlmecke, B., Kuhlbusch, T.A.J., Pui, D.Y.H., 2009. Conceptual limitations and extensions of lung-deposited Nanoparticle Surface Area Monitor (NSAM). Journal of Nanoparticle Research 11, 101-109.

Baltensperger, U., Weingartner, E., and, Burtscher, H., et al., 2001. Dynamic mass and surface area measurements., in: Baron, P., Willeke, K. (Eds.), Aerosol measurements: principles, techniques, and applications. John Wiley \& Sons., New York, pp. 387-418. Bau, S., Witschger, O., Gensdarmes, F., Thomas, D., 2012. Evaluating three direct-reading instruments based on diffusion charging to measure surface area concentrations in polydisperse nanoaerosols in molecular and transition regimes. Journal of Nanoparticle Research 14.

Betha, R., Spracklen, D.V., Balasubramanian, R., 2013. Observations of new aerosol particle formation in a tropical urban atmosphere. Atmospheric Environment 71, 340-351.

Brown, D.M., Wilson, M.R., MacNee, W., Stone, V., Donaldson, K., 2001. Size-dependent proinflammatory effects of ultrafine polystyrene particles: a role for surface area and oxidative stress in the enhanced activity of ultrafines. Toxicology and applied pharmacology 175, 191-199.

Brown, L.M., Collings, N., Harrison, R.M., Maynard, A.D., Maynard, R.L., 2000. Ultrafine Particles in the Atmosphere, Phil. Trans. R. Soc. Lond. A. The Royal Society, London, pp. 2563-2565.

Buonanno, G., Marini, S., Morawska, L., Fuoco, F.C., 2012. Individual dose and exposure of Italian children to ultrafine particles. The Science of the total environment 438, 271-277. Buonanno, G., Morawska, L., Stabile, L., Viola, A., 2010. Exposure to particle number, surface area and PM concentrations in pizzerias. Atmospheric Environment 44, 3963-3969. Carslaw, D., Beevers, S., Westmoreland, E., Williams, M., Tate, J., Murrells, T., Stedman, J., Li, Y., Grice, S., Kent, A., and Tsagatakis, I.,, 2011. Trends in NOx and NO2 emissions and ambient measurements in the UK. Defra report.

Carslaw, D.C., Beevers, S.D., Ropkins, K., Bell, M.C., 2006. Detecting and quantifying the contribution made by aircraft emissions to ambient concentrations of nitrogen oxides in the vicinity of a large international airport. Atmospheric Environment 40, 5424-5434.

Cordell, R.L., Mazet, M., Dechoux, C., Hama, S.M.L., Staelens, J., Hofman, J., Stroobants, C., Roekens, E., Kos, G.P.A., Weijers, E.P., Frumau, K.F.A., Panteliadis, P., Delaunay, T., Wyche, K.P., Monks, P.S., 2016. Evaluation of biomass burning across North West Europe and its impact on air quality. Atmos Environ 141, 276-286.

Eeftens, M., Phuleria, H.C., Meier, R., Aguilera, I., Corradi, E., Davey, M., Ducret-Stich, R., Fierz, M., Gehrig, R., Ineichen, A., Keidel, D., Probst-Hensch, N., Ragettli, M.S., Schindler, C., Künzli, N., Tsai, M.-Y., 2015. Spatial and temporal variability of ultrafine particles, NO2, 
PM2.5, PM2.5 absorbance, PM10 and PMcoarse in Swiss study areas. Atmospheric Environment 111, 60-70.

Fierz, M., Houle, C., Steigmeier, P., Burtscher, H., 2011. Design, Calibration, and Field Performance of a Miniature Diffusion Size Classifier. Aerosol Science and Technology 45, 110.

Fissan, H., Neumann, S., Trampe, A., Pui, D.Y.H., and, Shin, W.G., 2007. Rationale and principle of an instrument measuring lung deposited nanoparticle surface area. J. Nanoparticle Res 9, 53-59. measurements in selected occupational and non-occupational environments. Journal of Aerosol Science 96, 24-37.

Gomes, J.F., Bordado, J.C., Albuquerque, P.C., 2012. On the assessment of exposure to airborne ultrafine particles in urban environments. Journal of toxicology and environmental health. Part A 75, 1316-1329.

Gomišček, B., Hauck, H., Stopper, S., Preining, O., 2004. Spatial and temporal variations of PM1, PM2.5, PM10 and particle number concentration during the AUPHEP_- project.

Atmospheric Environment 38, 3917-3934.

Harrison, R.M., Deacon, A.R., Jones, M.R., and, Appleby, R.S., 1997. Sources and processes affecting concentrations of PM10 and PM2.5 particulate matter in Birmingham. Atmospheric Environment 31, 4103-4117.

Heintzenberg, J., Wehner, B., Birmili, W., 2007. How to find bananas in the atmospheric aerosol?: new approach for analyzing atmospheric nucleation and growth events. Tellus B 59, 273-282.

Hofman, J., Staelens, J., Cordell, R., Stroobants, C., Zikova, N., Hama, S.M.L., Wyche, K.P., Kos, G.P.A., Van Der Zee, S., Smallbone, K.L., Weijers, E.P., Monks, P.S., Roekens, E., 2016. Ultrafine particles in four European urban environments: Results from a new continuous long-term monitoring network. Atmos Environ 136, 68-81. Hussein, T., Martikainen, J., Junninen, H., Sogacheva, L., Wagner, R., Dal Maso, M., Riipinen, I., Aalto, P.P., Kulmala, M., 2008. Observation of regional new particle formation in the urban atmosphere. Tellus B 60, 509-521. Imhof, D., Weingartner, E., Vogt, U., Dreiseidler, A., Rosenbohm, E., Scheer, V., Vogt, R., Nielsen, O.J., Kurtenbach, R., Corsmeier, U., Kohler, M., Baltensperger, U., 2005. Vertical distribution of aerosol particles and NOx close to a motorway. Atmospheric Environment 39, 5710-5721.

Joaquin, 2015. Monitoring of ultrafine particles and black carbon. Joint Air Quality Initiative Work Package 1 Action 1 and 3.

Johnston, C.J., Finkelstein, J.N., Mercer, P., Corson, N., Gelein, R., Oberdorster, G., 2000. Pulmonary effects induced by ultrafine PTFE particles. Toxicology and applied pharmacology 168, 208-215.

Jones, A.M., Harrison, R.M., 2005. Interpretation of particulate elemental and organic carbon concentrations at rural, urban and kerbside sites. Atmospheric Environment 39, 7114-7126. Karlsson, H.L., Gustafsson, J., Cronholm, P., Moller, L., 2009. Size-dependent toxicity of metal oxide particles--a comparison between nano- and micrometer size. Toxicology letters $188,112-118$.

Kulmala, M., Kerminen, V.-M., 2008. On the formation and growth of atmospheric nanoparticles. Atmospheric Research 90, 132-150.

Kuuluvainen, H., Rönkkö, T., Järvinen, A., Saari, S., Karjalainen, P., Lähde, T., Pirjola, L., Niemi, J.V., Hillamo, R., Keskinen, J., 2016. Lung deposited surface area size distributions of particulate matter in different urban areas. Atmospheric Environment 136, 105-113. 
Laxen, D., Moorcroft, S., Marner, B., Laxen, K., Boulter, P., Barlow, T., Harrison, R., and, Heal, M., 2010. PM2.5 in the UK, Report for SNIFFER, Edinburgh Available at: http://www.aqconsultants.co.uk/AQC/media/Reports/SNIFFER-PM25-Rept-Final201210.pdf. LeBlanc, A.J., Moseley, A.M., Chen, B.T., Frazer, D., Castranova, V., Nurkiewicz, T.R., 2010. Nanoparticle inhalation impairs coronary microvascular reactivity via a local reactive oxygen species-dependent mechanism. Cardiovascular toxicology 10, 27-36. Ma, N., Zhao, C.S., Nowak, A., Müller, T., Pfeifer, S., Cheng, Y.F., Deng, Z.Z., Liu, P.F., Xu, W.Y., Ran, L., Yan, P., Göbel, T., Hallbauer, E., Mildenberger, K., Henning, S., Yu, J., Chen, L.L., Zhou, X.J., Stratmann, F., Wiedensohler, A., 2011. Aerosol optical properties in the North China Plain during HaChi campaign: an in-situ optical closure study. Atmospheric Chemistry and Physics 11, 5959-5973.

Maynard, A.D., Maynard, R.L., 2002. A derived association between ambient aerosol surface area and excess mortality using historic time series data. Atmospheric Environment 36, 55615567.

Mohr, M., Lehmann, U., and, Rutter, J., 2005. Comparison of Mass-Based and Non-MassBased Particle Measurement Systems for Ultra-Low Emissions from Automotive Sources. Environ. Sci. Technol 39, 2229-2238.

Moshammer, H., Neuberger, M., 2003. The active surface of suspended particles as a predictor of lung function and pulmonary symptoms in Austrian school children. Atmospheric Environment 37, 1737-1744.

Nel, A., Xia, T., Mädler, L., and, Li, N., 2006. Toxic Potential of Materials at the Nanolevel. SCIENCE 311, 622-627.

Ntziachristos, L., Polidori, A., Phuleria, H., Geller, M.D., Sioutas, C., 2007. Application of a Diffusion Charger for the Measurement of Particle Surface Concentration in Different Environments. Aerosol Science and Technology 41, 571-580.

Nurkiewicz, T.R., Porter, D.W., Hubbs, A.F., Stone, S., Chen, B.T., Frazer, D.G., Boegehold, M.A., Castranova, V., 2009. Pulmonary nanoparticle exposure disrupts systemic microvascular nitric oxide signaling. Toxicological sciences : an official journal of the Society of Toxicology 110, 191-203.

Nygaard, U.C., Samuelsen, M., Aase, A., and, Lovik, M., 2004. The capacity of particles to increase allergic sensitization is predicted by particle number and surface area, not by particle mass. Toxicological sciences : an official journal of the Society of Toxicology 82, 515-524. Oberdörster, G., 2000. Toxicology of ultrafine particles: in vivo studies. Phil. Trans. R. Soc. Lond. A 358, 2719-2740.

Oberdörster, G., Maynard, A., Donaldson, K., Castranova, V., Fitzpatrick, J., Ausman, K., Carter, J., Karn, B., Kreyling, W., Lai, D., Olin, S., Monteiro-Riviere, N., Warheit, D., Yang, H., 2005. Principles for characterizing the potential human health effects from exposure to nanomaterials: elements of a screening strategy. Particle and fibre toxicology 2, 1-35.

Peters, T.M., Elzey, S., Johnson, R., Park, H., Grassian, V.H., Maher, T., O'Shaughnessy, P., 2009. Airborne monitoring to distinguish engineered nanomaterials from incidental particles for environmental health and safety. Journal of occupational and environmental hygiene 6 , 73-81.

Petzold, A., Kramer, H., and, Schönlinner, M., 2002. Continuous measurement of atmospheric black carbon using a Multi-angle absorption photometer. Environ Sci Pollut Res 4, 78-82.

Petzold, A., Ogren, J.A., Fiebig, M., Laj, P., Li, S.M., Baltensperger, U., Holzer-Popp, T., Kinne, S., Pappalardo, G., Sugimoto, N., Wehrli, C., Wiedensohler, A., Zhang, X.Y., 2013. 
Recommendations for reporting "black carbon" measurements. Atmospheric Chemistry and Physics 13, 8365-8379.

Pósfai, M., Gelencsér, A., Simonics, R., Arató, K., Li, J., Hobbs, P.V., Buseck, P.R., 2004. Atmospheric tar balls: Particles from biomass and biofuel burning. Journal of Geophysical Research: Atmospheres 109, n/a-n/a.

Reche, C., Querol, X., Alastuey, A., Viana, M., Pey, J., Moreno, T., Rodríguez, S., González, Y., Fernández-Camacho, R., de la Rosa, J., Dall'Osto, M., Prévôt, A.S.H., Hueglin, C., Harrison, R.M., Quincey, P., 2011. New considerations for PM, Black Carbon and particle number concentration for air quality monitoring across different European cities. Atmospheric Chemistry and Physics 11, 6207-6227.

Reche, C., Viana, M., Brines, M., Perez, N., Beddows, D., Alastuey, A., Querol, X., 2015. Determinants of aerosol lung-deposited surface area variation in an urban environment. The Science of the total environment 517, 38-47.

Sager, T.M., Castranova, V., 2009. Surface area of particle administered versus mass in determining the pulmonary toxicity of ultrafine and fine carbon black: comparison to ultrafine titanium dioxide. Particle and fibre toxicology $6,15$.

Schwarz, J.P., Gao, R.S., Fahey, D.W., Thomson, D.S., Watts, L.A., Wilson, J.C., Reeves, J.M., Darbeheshti, M., Baumgardner, D.G., Kok, G.L., Chung, S.H., Schulz, M., Hendricks, J., Lauer, A., Kärcher, B., Slowik, J.G., Rosenlof, K.H., Thompson, T.L., Langford, A.O., Loewenstein, M., Aikin, K.C., 2006. Single-particle measurements of midlatitude black carbon and light-scattering aerosols from the boundary layer to the lower stratosphere. Journal of Geophysical Research 111.

Singh, S., Shi, T., Duffin, R., Albrecht, C., van Berlo, D., Hohr, D., Fubini, B., Martra, G., Fenoglio, I., Borm, P.J., Schins, R.P., 2007. Endocytosis, oxidative stress and IL-8 expression in human lung epithelial cells upon treatment with fine and ultrafine TiO2: role of the specific surface area and of surface methylation of the particles. Toxicology and applied pharmacology 222, 141-151.

Spinazzè, A., Cattaneo, A., Scocca, D.R., Bonzini, M., Cavallo, D.M., 2015. Multi-metric measurement of personal exposure to ultrafine particles in selected urban microenvironments. Atmospheric Environment 110, 8-17.

Stoeger, T., Reinhard, C., Takenaka, S., Schroeppel, A., Karg, E., Ritter, B., Heyder, J., Schulz, H., 2006. Instillation of Six Different Ultrafine Carbon Particles Indicates a Surface Area Threshold Dose for Acute Lung Inflammation in Mice. Environmental Health Perspectives 114, 328-333.

Tran, C.L., Buchanan, D., Cullen, R.T., Searl, A., Jones, A.D., Donaldson, K., 2000. Inhalation of poorly soluble particles. II. Influence Of particle surface area on inflammation and clearance. Inhalation toxicology 12, 1113-1126. Viana, M., Querol, X., Alastuey, A., Reche , C., Favez, O., Malherbe, L., Ustache, A., Bartonova, A., Liu, H., Guerreiro, C., , 2012. Particle number (PNC) and black carbon (BC) in European urban air quality networks. ETC/ACM Technical Paper.

Wehner, B., and, Wiedensohler, A., 2003. Long term measurements of submicrometer urban aerosols: statistical analysis for correlations with meteorological conditions and trace gases. Atmos. Chem. Phys 3, 867-879.

Wiedensohler, A., 1988. An approximation of the bipolar charge distribution for particles in the submicron size range. Journal of Aerosol Science 19, 387-389.

Wiedensohler, A., Birmili, W., Nowak, A., Sonntag, A., Weinhold, K., Merkel, M., Wehner, B., Tuch, T., Pfeifer, S., Fiebig, M., Fjäraa, A.M., Asmi, E., Sellegri, K., Depuy, R., Venzac, H., Villani, P., Laj, P., Aalto, P., Ogren, J.A., Swietlicki, E., Williams, P., Roldin, P., Quincey, P., Hüglin, C., Fierz-Schmidhauser, R., Gysel, M., Weingartner, E., Riccobono, F., 
1 Santos, S., Grüning, C., Faloon, K., Beddows, D., Harrison, R., Monahan, C., Jennings, S.G., 2 O'Dowd, C.D., Marinoni, A., Horn, H.G., Keck, L., Jiang, J., Scheckman, J., McMurry, P.H., 3 Deng, Z., Zhao, C.S., Moerman, M., Henzing, B., de Leeuw, G., Löschau, G., Bastian, S., 4 2012. Mobility particle size spectrometers: harmonization of technical standards and data 5 structure to facilitate high quality long-term observations of atmospheric particle number size 6 distributions. Atmospheric Measurement Techniques 5, 657-685.

7 Wilson, W.E., Stanek, J., Han, H.-S., Johnson, T., Sakurai, H., Pui, D.Y.H., and, J.T., Chen, 8 D.-R., Duthie, S., 2007. Use of the Electrical Aerosol Detector as an Indicator of the Surface 9 Area of Fine Particles Deposited in the Lung. Journal of the Air \& Waste Management 10 Association 57, 211-220.

11 Xu, W.Y., Zhao, C.S., Ran, L., Deng, Z.Z., Liu, P.F., Ma, N., Lin, W.L., Xu, X.B., Yan, P., $12 \mathrm{He}, \mathrm{X} ., \mathrm{Yu}$, J., Liang, W.D., Chen, L.L., 2011. Characteristics of pollutants and their 13 correlation to meteorological conditions at a suburban site in the North China Plain. 14 Atmospheric Chemistry and Physics 11, 4353-4369. 
Table 1: Instruments and Monitors used in this study (for details, see experimental).

1

\begin{tabular}{cccccccc}
\hline Station & Location & $\begin{array}{c}\text { Metrological } \\
\text { Parameters }\end{array}$ & NSAM & W-CPC & SMPS & NOx & MAAP \\
\hline AURN & UoL & - & x & x & - & x & x \\
Trailer(Mobile & UoL and & x & - & x & x & - & x \\
Campaign) & BF & & & & & &
\end{tabular}

2

3 Table 2: Statistics of LDSA $\left(\mu \mathrm{m}^{2} \mathrm{~cm}^{-3}\right)$, eBC $\left(\mu \mathrm{g} \mathrm{m}^{-3}\right)$, and $\mathrm{NO}_{\mathrm{X}}\left(\mu \mathrm{g} \mathrm{m} \mathrm{m}^{-3}\right)$ measured at AURN

4 site from November 2013 to May 2015.

\begin{tabular}{ccccccc}
\hline Parameters & & Average & Max & Median & Min & St. Dev. \\
\hline LDSA & Annual & 29.5 & 282.8 & 22.3 & 0.1 & 24.8 \\
eBC & 1.4 & 13 & 1.07 & 0.06 & 1.3 \\
NOX & Cold Period & 38 & 596.7 & 27.6 & 0.43 & 35.2 \\
LDSA & & 282.8 & 28.2 & 0.55 & 33 \\
eBC & 1.84 & 13.5 & 1.26 & 0.85 & 1.8 \\
NOX & Warm Period & 23 & 596.7 & 34.1 & 2.06 & 46.8 \\
LDSA & 1.25 & 146 & 20.2 & 0.1 & 13.7 \\
eBC & 29 & 13 & 1.02 & 0.06 & 0.96 \\
NOX & & 231.8 & 24.6 & 0.43 & 20.6 \\
\hline
\end{tabular}

5

6

7 
1 Table 3: Summary of average and standard deviations of LDSA (Alveolar region)

2 concentrations $\left(\mu \mathrm{m}^{2} \mathrm{~cm}^{-3}\right)$ measured in previous studies and this study in urban areas.

\begin{tabular}{|c|c|c|c|}
\hline Site & $\begin{array}{l}\operatorname{LDSA}\left(\mu \mathrm{m}^{2}\right. \\
\left.\mathrm{cm}^{-3}\right)\end{array}$ & St .Dev. & Study \\
\hline $\begin{array}{l}\text { Urban background site (Los Angeles) retirement } \\
\text { community (outdoor) }\end{array}$ & 68.9 & 38.7 & $\begin{array}{l}\text { Ntziachristos et al. } \\
\text { (2007) }\end{array}$ \\
\hline Urban background site (Los Angeles) & 53 & 27.5 & \\
\hline Freeway 1 (Los Angeles) & 105.8 & 48.3 & \\
\hline Freeway 2 (Los Angeles) & 153.4 & 55.2 & \\
\hline Highway (Zurich) & 40 & & Fierz et al. (2011) \\
\hline Busy city road-1 (Zurich) & 63 & & \\
\hline Busy city road-2 (Zurich) & 63 & & \\
\hline $\begin{array}{l}\text { Urban background site, inner city, little traffic } \\
\text { (Zurich) }\end{array}$ & 19 & & \\
\hline Average city road (Zurich) & 28 & & \\
\hline Urban background site, no traffic (Zurich) & 11 & & \\
\hline Urban background site (Cassino) & 164 & & Buonanno et al. \\
\hline Rural background site (Cassino) & 69 & & (2012) \\
\hline Urban background site (Lisbon) & $35-89$ & & Gomes et al. (2012) \\
\hline $\begin{array}{l}\text { Urban background site with traffic influence } \\
\text { (Barcelona) }\end{array}$ & 37 & 26 & (Reche et al. (2015)) \\
\hline Park area and traffic site (Helsinki) & $12-94$ & & $\begin{array}{l}\text { (Kuuluvainen et al. } \\
\text { (2016)) }\end{array}$ \\
\hline $\begin{array}{l}\text { Urban background site with traffic influence } \\
\text { (Leicester) }\end{array}$ & 29.9 & 24.85 & This Study \\
\hline
\end{tabular}




\section{1}
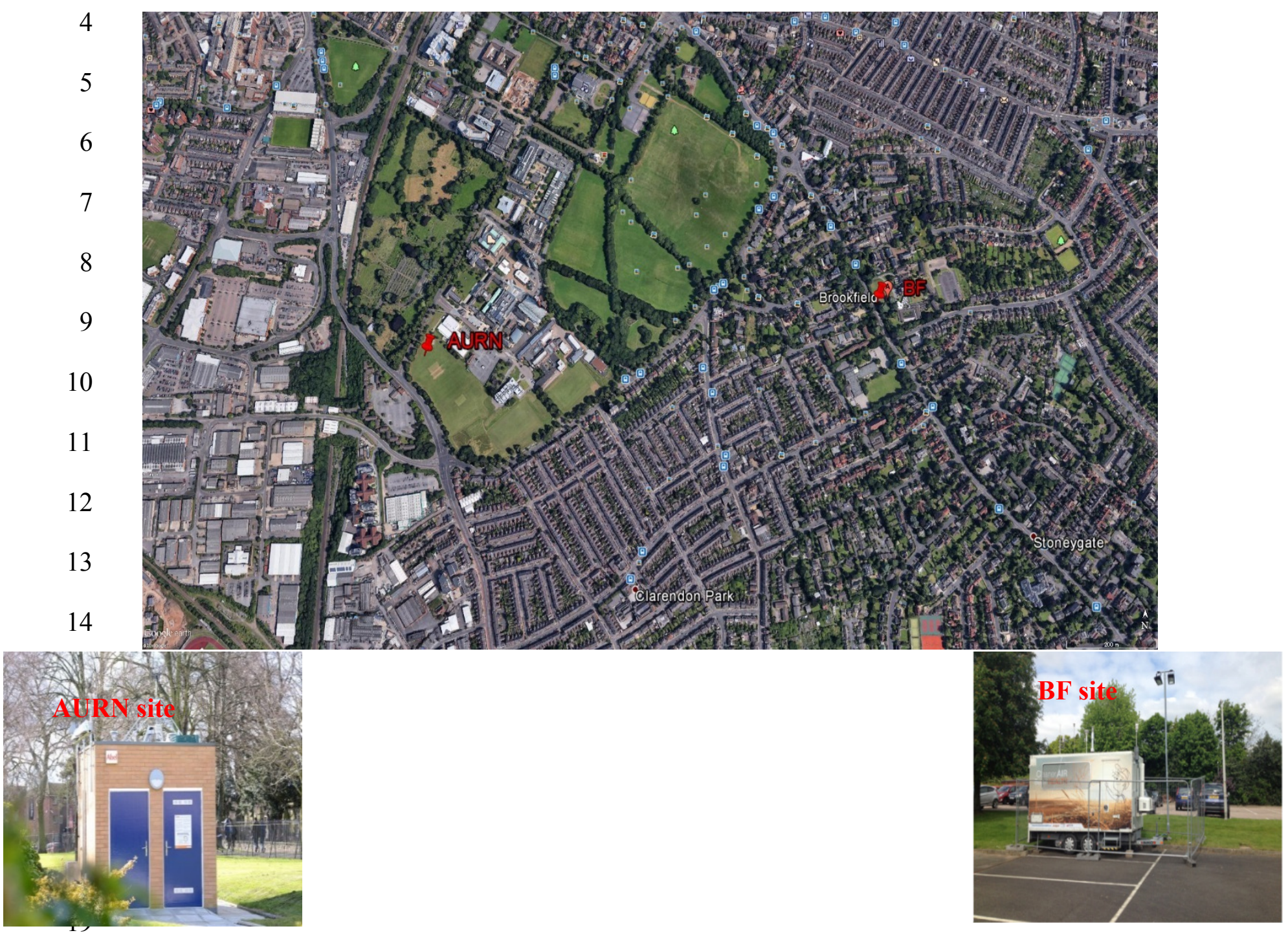

Figure 1: AURN and Brookfield site at Leicester University campus, sampling location. 

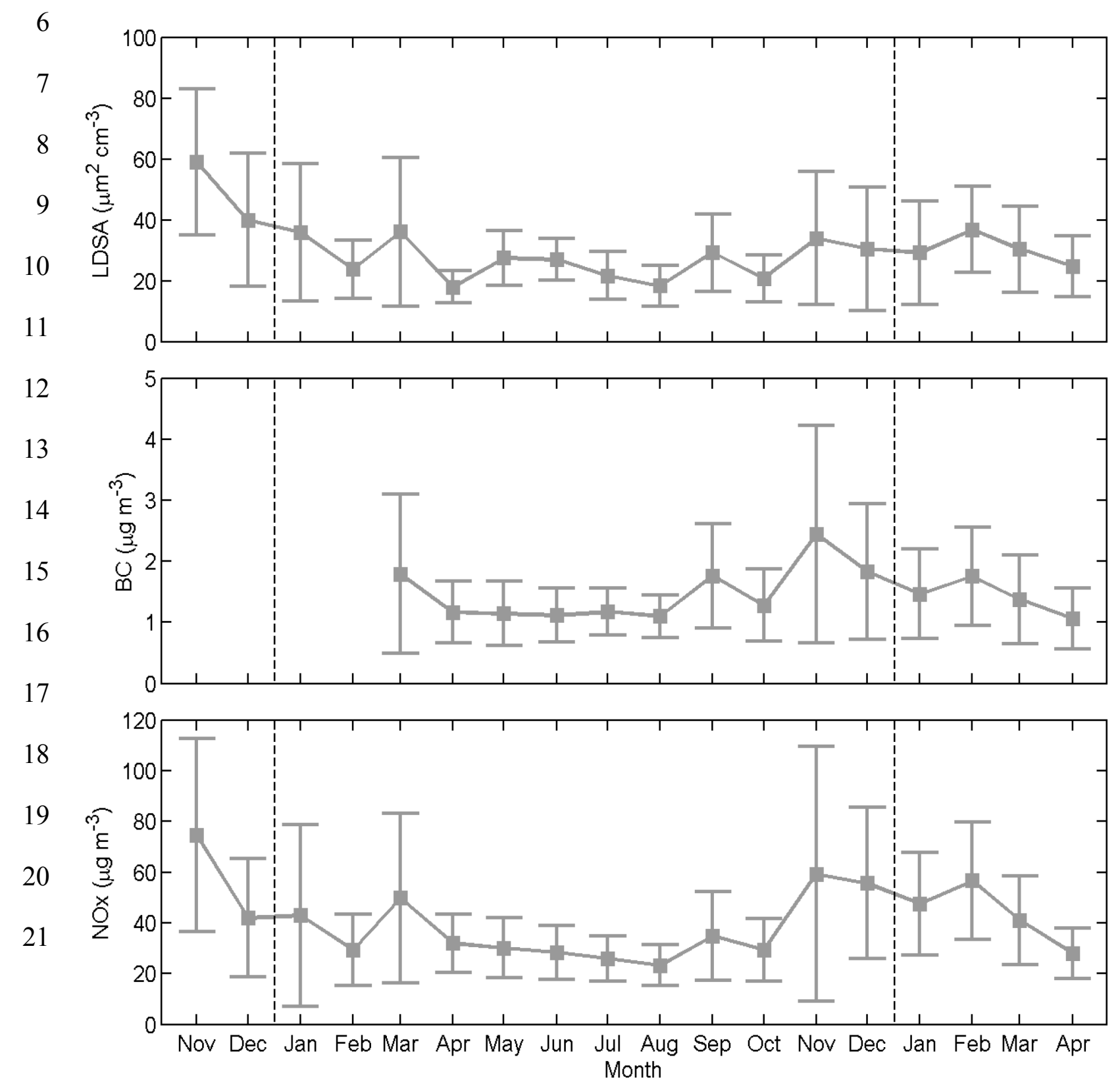

Figure 2: Monthly variations of LDSA, eBC, and $\mathrm{NO}_{\mathrm{X}}$ concentrations (error bars represent the standard deviation). 

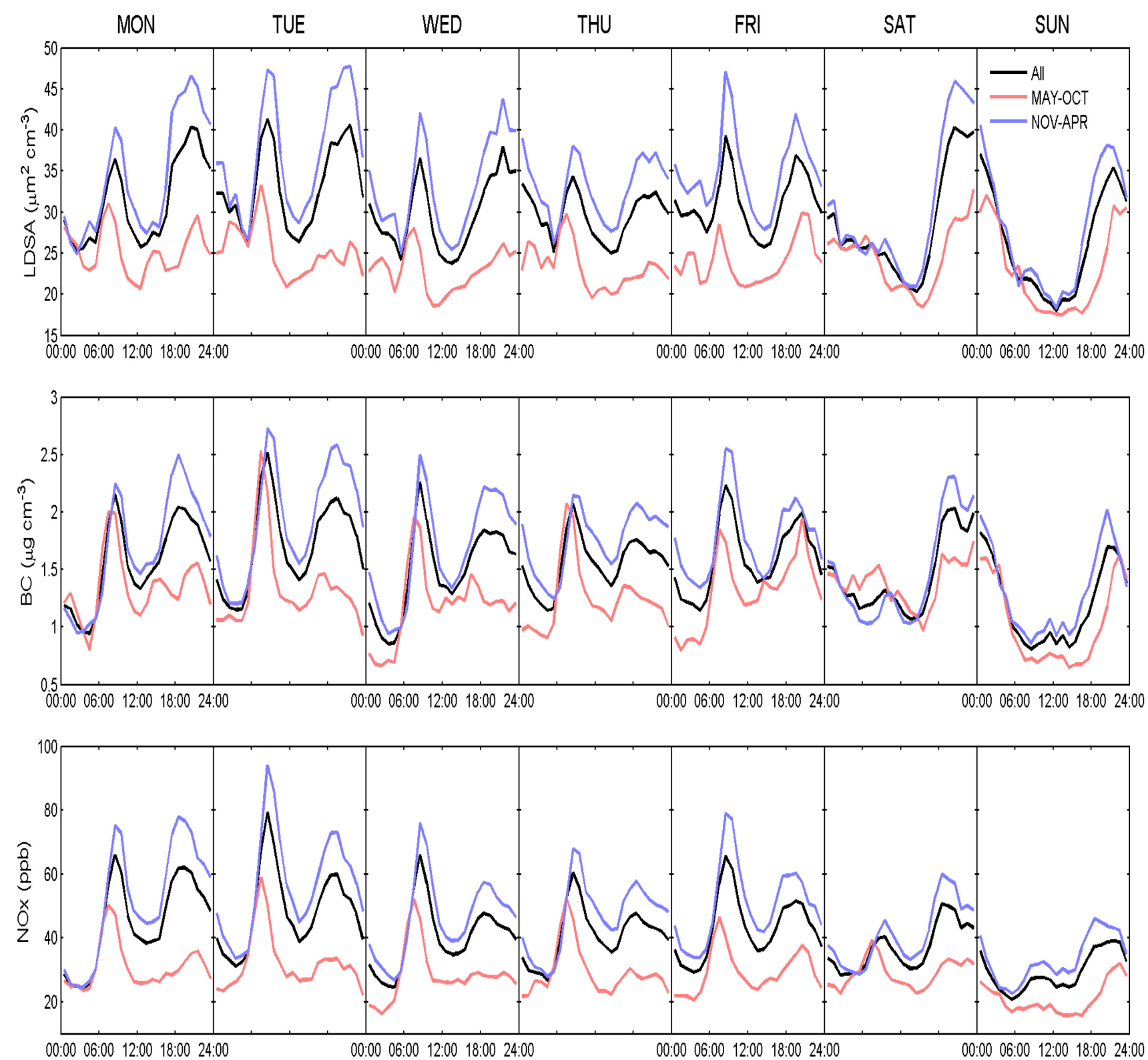

Figure 3: The diurnal and weekly variations of LDSA, eBC, and $\mathrm{NO}_{\mathrm{x}}$ concentrations. 
4

5

6

7

8

9

10

11

12

13

14

15

16

17

18

19

20

21

22

23

25

2
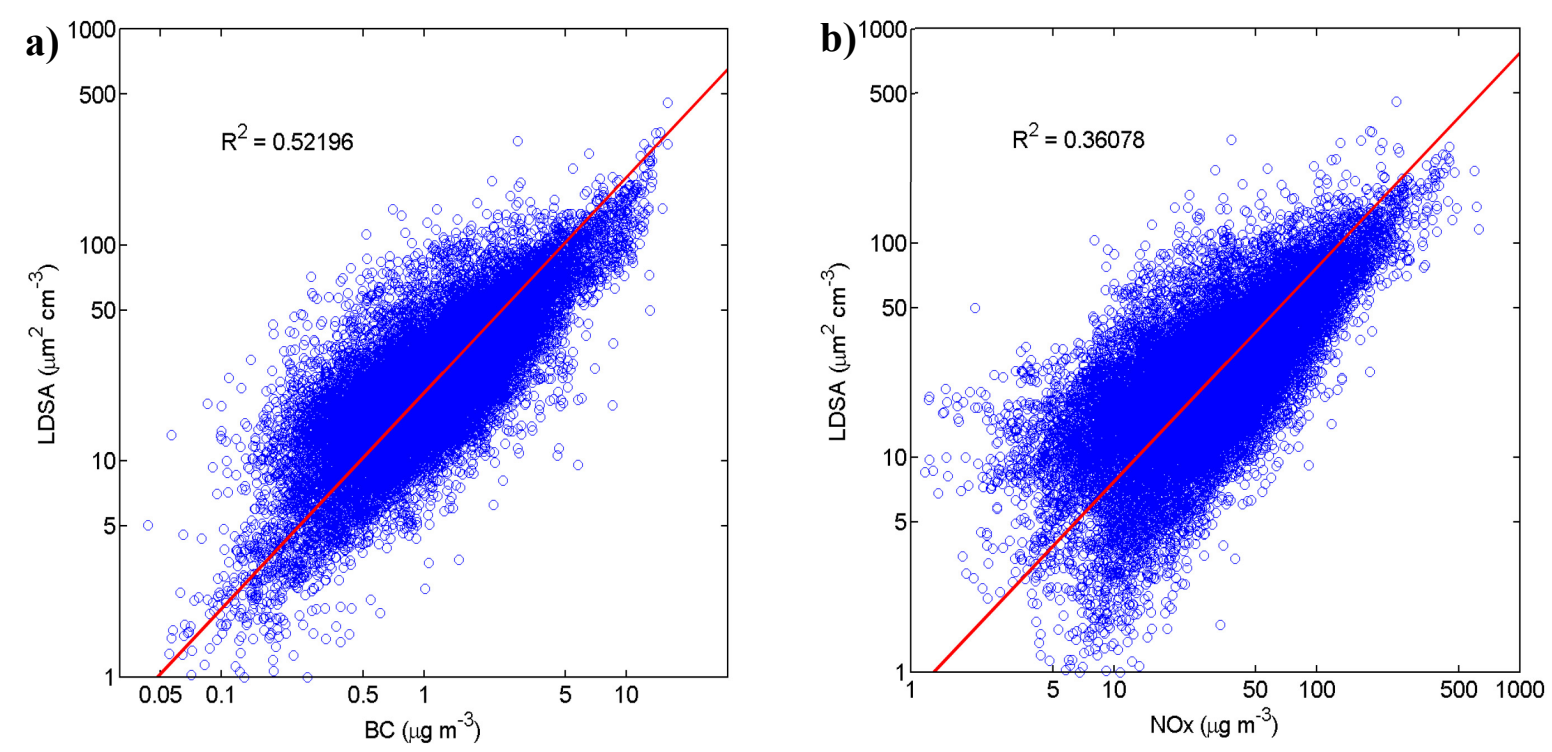

3

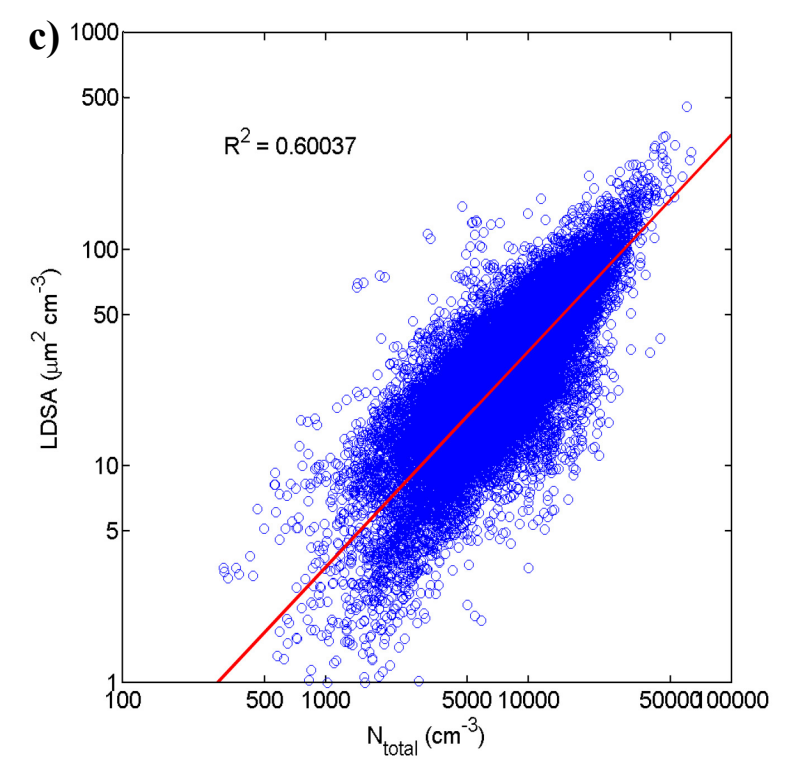

Figure 4: Correlations between LDSA concentrations and (a) Black Carbon (eBC), (b) $\mathrm{NO}_{\mathrm{X}}$, (c) 3 Total Particle Number concentration (NTOTAL) at AURN monitoring site from Nov-2013 to Apr2015. 


\section{3}

4

5

6

7

8

9

10

11

12

13

14

15

16

17

18

19

20

21

22

23

24

25

26 $\begin{array}{lll}0.1 & 1 & 10\end{array}$

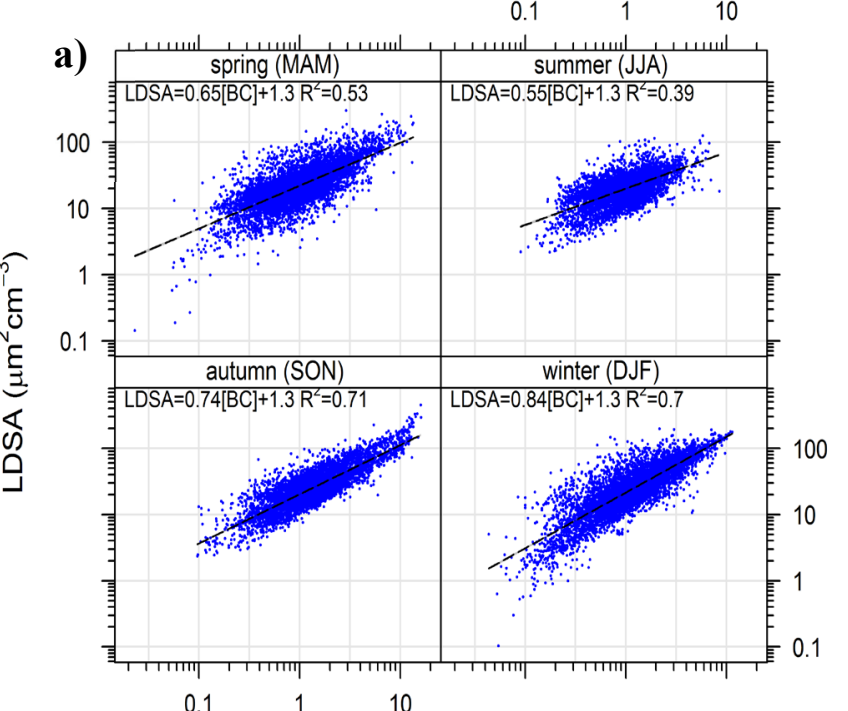

BC $\left(\mu \mathrm{gm}^{-3}\right)$
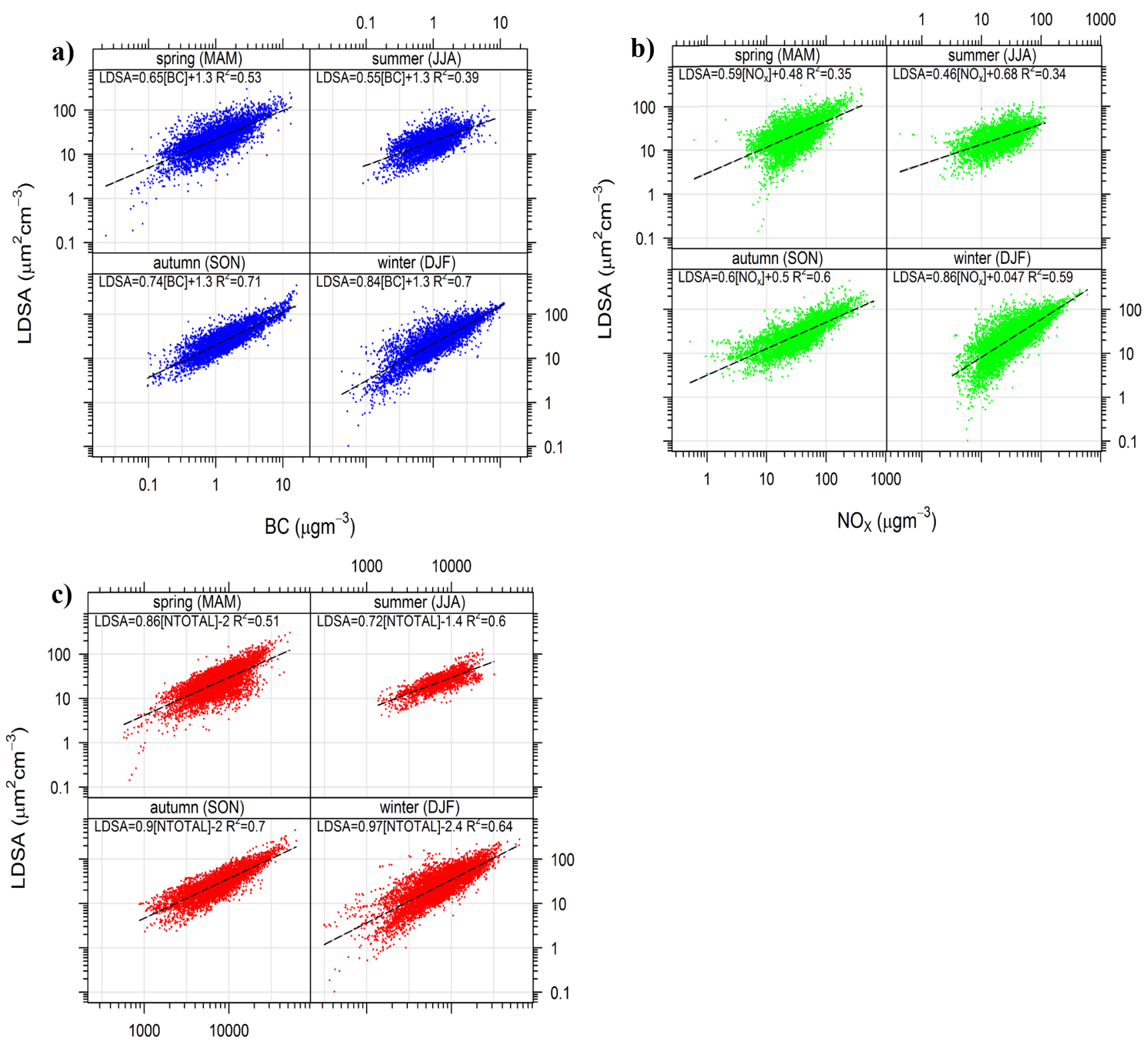

$\mathrm{N}_{\text {TOTAL }}\left(\mathrm{cm}^{-3}\right)$

2 Figure 5: Seasonal correlations between LDSA concentrations and (a) Black Carbon (eBC), (b) NOx, (c) Total Particle Number concentration (NTOTAL) at AURN monitoring site from Nov-2013 to Apr-2015. 

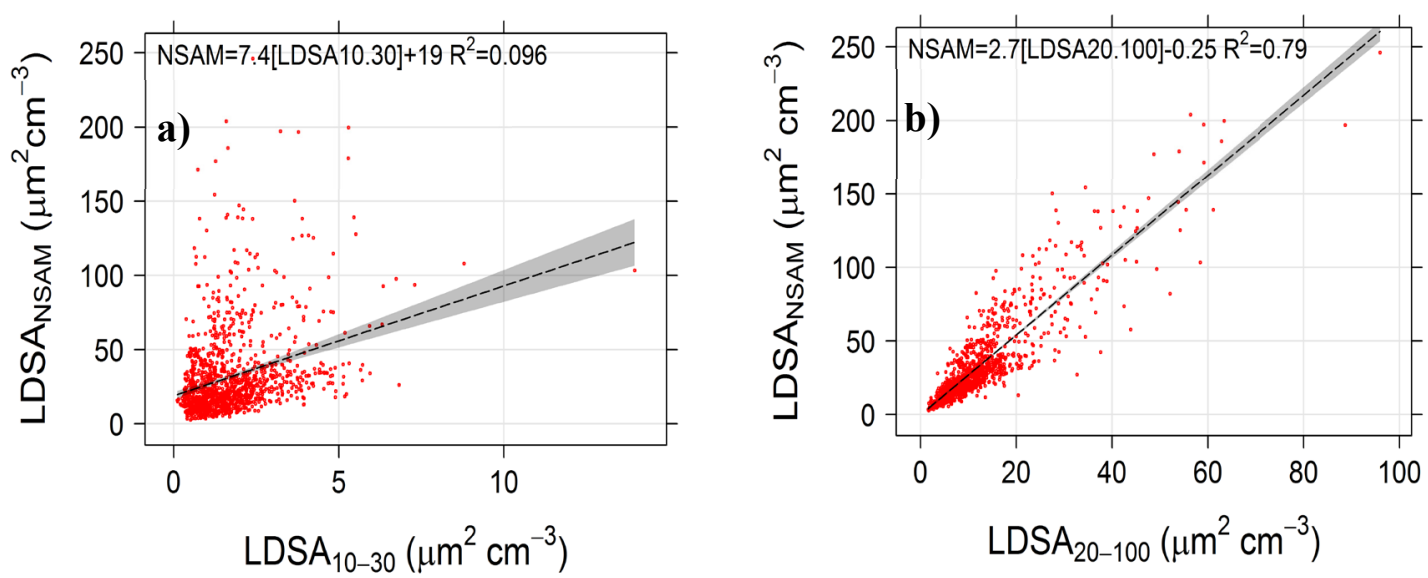

9

10

11

12
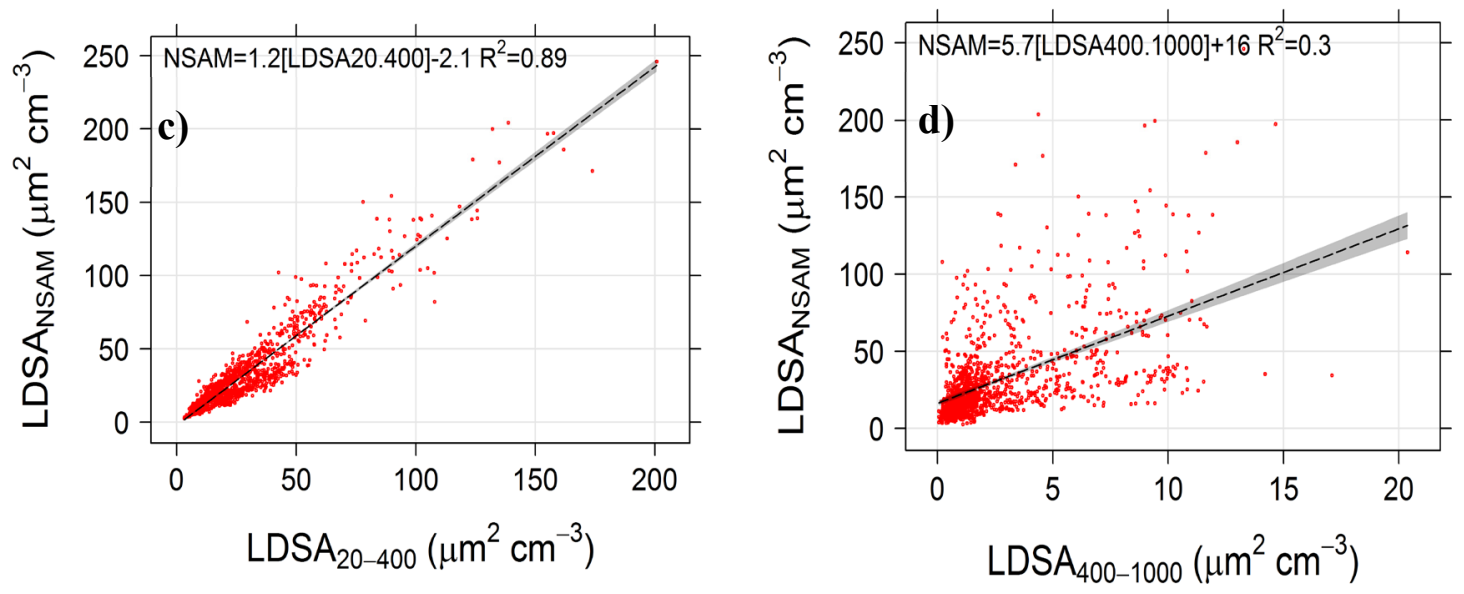

Figure 6: Linear relationship between direct LDSA (from NSAM) and calculated LDSA (from PNSD) concentrations for different particle size ranges, a) 10-30 nm b) 20-100 nm, 18 

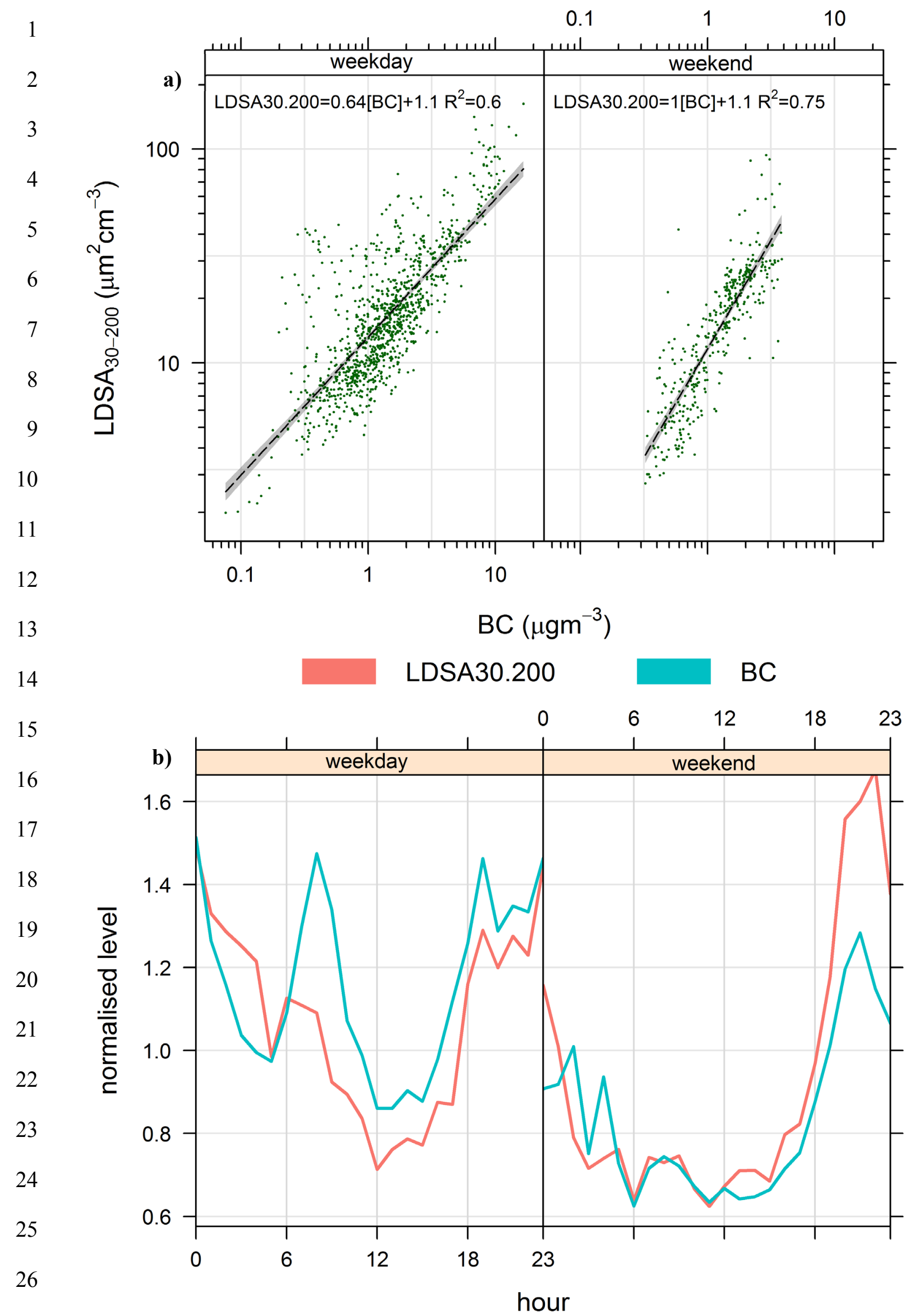

Figure 7: Linear relationships between the calculated LDSA and eBC: (a) scatterplots for weekdays and weekends, (b) diurnal variation of the calculated LDSA and eBC 
a)

1

2

3

4

5

6

7

8

9

10

11

12

13

14

15

16

17

18

19

20

21

22

23

24

c)

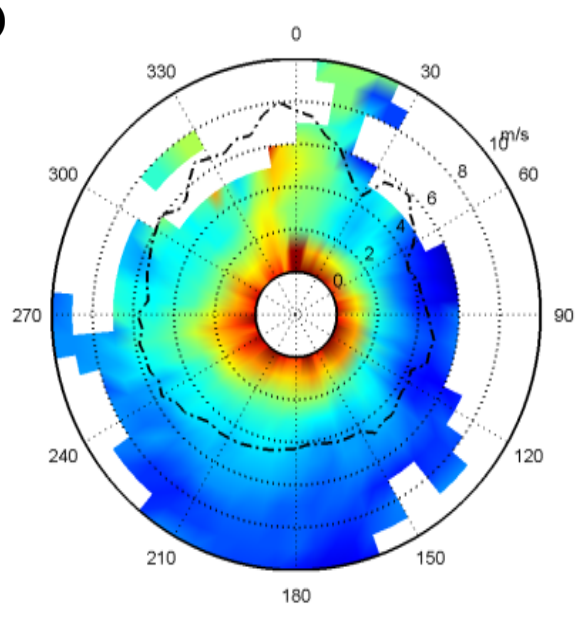
direction. b)
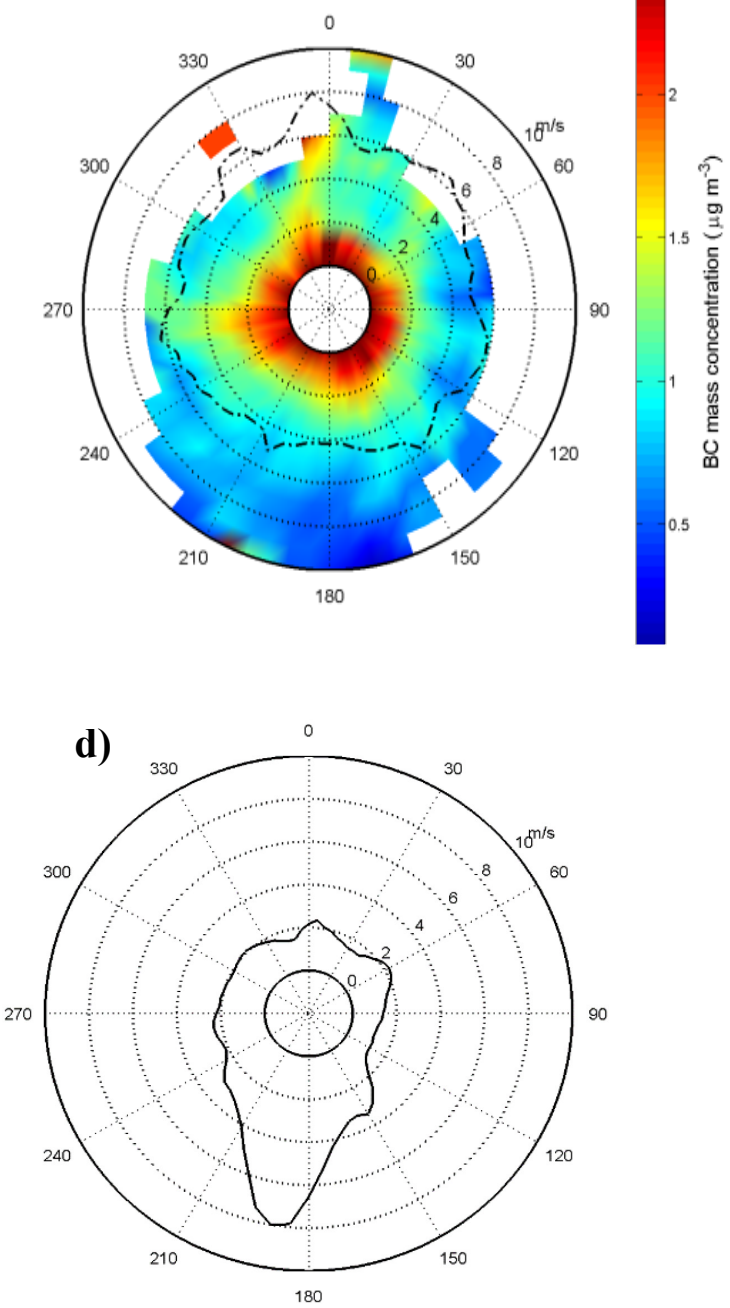

Figure 8: Wind speed and direction dependence map of a) LDSA $\left.\left.\left(\mu \mathrm{g}^{2} / \mathrm{cm}^{3}\right), \mathrm{b}\right) \mathrm{eBC}\left(\mu \mathrm{g} / \mathrm{m}^{3}\right), \mathrm{c}\right) \mathrm{NOx}$ $\left(\mu \mathrm{g} / \mathrm{m}^{3}\right)$ at AURN site, $\left.\mathrm{d}\right)$ wind frequency rose for the whole period. In each figure, the shaded contour indicates the average of variables for varying wind speeds (radial direction) and wind direction (transverse direction). The dash-dot lines stand for the relative mean values for each wind 

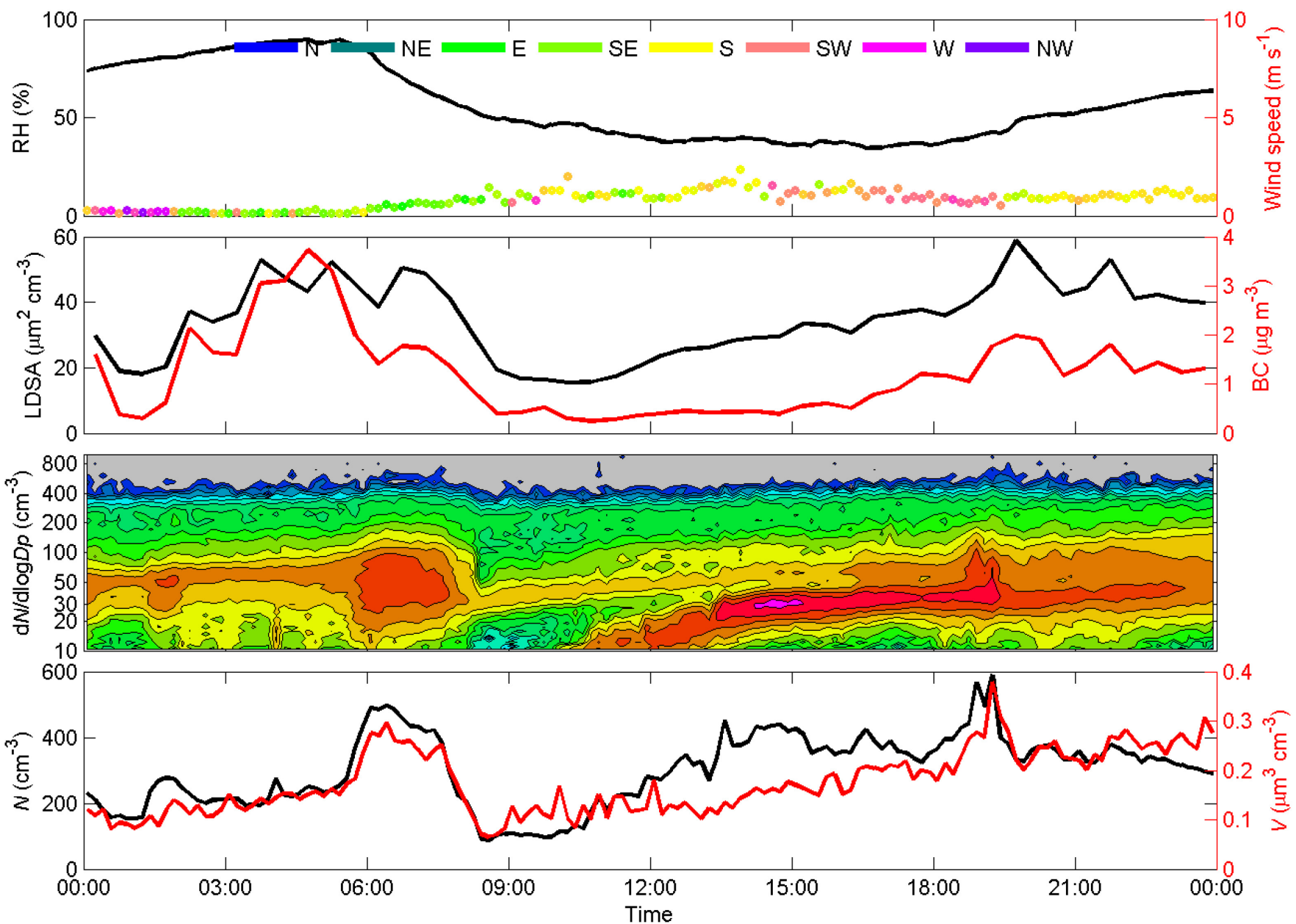

Figure 9: Contour plot of particle size distribution observed on $3^{\text {rd }}$ May 2014. From bottom to top, the parameters are: (i) total Particle number and volume concentrations, (ii) contour plot of particle size distributions, (iii) LDSA and eBC concentrations (iv)wind speed and relative humidity. 

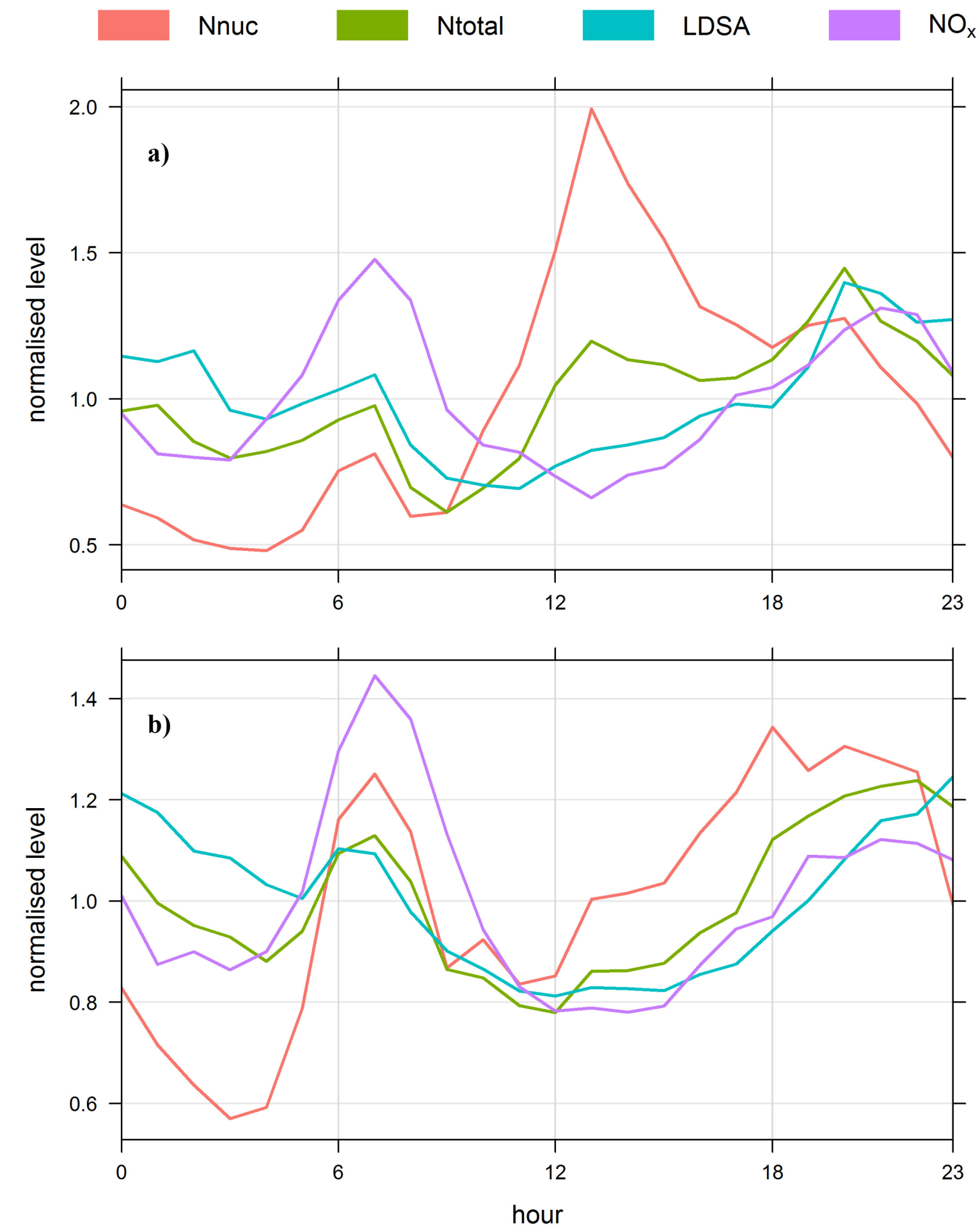

20 Figure 10: Diurnal variation of PNSD, LDSA, and NOx for a) NPF event days ( $\mathrm{n}=14)$, and $b)$ 21 Non-NPF event days $(n=72)$. Nnuc is the particle number concentrations when diameter 10 $25 \mathrm{~nm}$ and Ntotal $=$ Particle number concentrations with diameter $=10-1000 \mathrm{~nm}$. 